\title{
RELIGIOUS INCLUSIVITY IN ISLAMIC EDUCATION COURSE BOOK OF THE 2013 CURRICULUM
}

\author{
Bambang Qomaruzzaman \\ Post-Graduate Program, Universitas Islam Negeri (UIN) Sunan Gunung Djati, Bandung \\ Jl.AH Nasution No.105 Cibiru, Bandung, West Java, Indonesia \\ E-mail: bambang.q.anees@uinsgd.ac.id
}

\begin{abstract}
Religious Inclusivity in Islamic Education Course Book of the 2013 Curriculum. A survey of Center for the Study of Islam and Society (PPIM) in 2017 states that Islamic Education course is one of the triggers for the rise of intolerant attitudes and thoughts in the younger generation of Indonesian Muslims. This background encourages this paper to examine the content of tolerance in Islamic Education textbook of the 2013 curriculum. This study is a library research using Fairclough's Critical Discourse method for senior high school's Islamic Education textbooks of X, XI, and XII grade. The results of the study show that, (1) the general framework of the 2013 curriculum is oriented towards building an inclusive generation of young Muslims, but the textbooks are ambiguous, (2) the discourse battle between substantive Islam and Islamism in the curriculum causes ambiguity in the textbooks, and (3) the book's producers are not official institution of Islam, therefore the course's teaching material is personal, as the author's personal opinion. Implementation and limitation of papers are presented at the end of this paper.
\end{abstract}

Keywords: Islamic education course; religious inclusivity; the 2013 Curriculum.

Abstrak: Inklusivitas Agama dalam Buku Pendidikan Agama Islam (PAI) pada Kurikulum 2013. Survey Pusat Pengkajian Islam dan Masyarakat (PPIM) tahun 2017 yang mengemukakan bahwa Pendidikan Agama Islam (PAI) menjadi salah satu pemicu maraknya sikap dan pikiran intoleran pada generasi muda Islam Indonesia mendorong tulisan ini untuk memeriksa muatan toleransi pada buku PAI, Kurikulum 2013. Penelitian ini merupakan studi pustaka dengan menggunakan metode Critical Discourse Analisys Fair clough terhadap buku ajar PAI Sekolah Menengah Atas (SMA) kelas X dan XI. Hasil penelitian menunjukkan, (1) kerangka umum Kurikulum 2013 berorientasi membangun Generasi muda Islam yang inklusif, namun buku ajar PAI bersifat ambigu, (2) adanya pertarungan wacana antara Islam substantive dan Islamisme pada kurikulum menjadi penyebab ambiguitas buku ajar PAI, dan (3) produsen buku PAI ternyata bukanlah lembaga resmi agama Islam, karena itu materi ajar PAI bersifat personal, sebagai opini pribadi penulis. Implementasi dan limitasi tulisan dikemukakan pada bagian akhir kesimpulan.

Kata kunci: Pendidikan Agama Islam; inklusivitas agama; Kurikulum 2013.

\section{Introduction}

Indonesian Muslim adolescents, according to several popular PPIM surveys, 'Setara², show a tendency to have intolerant attitudes or understandings. This intolerance is allegedly derived from teaching materials of Islamic

${ }^{1}$ Pusat Pengkajian Islam dan Masyarakat (PPIM) UIN Syarif Hidayatullah Jakarta, "Api dalam Sekam: Keberagamaan gen Z: Survei Nasional tentang Sikap Keberagamaan di Sekolah dan Universitas di Indonesia",(Jakarta: PPIM,2017), p. 1-10.

2 Setara Institute, Survey Report, "Toleransi Siswa SMA Negeri di Jakarta \& Bandung Raya" (Jakarta: Setara Institute, 2016), p. 32.
Education PPIM ${ }^{3}$, Setara ${ }^{4}$ and even the course teachers (PPIM)5. The results of this survey indicate a turning point from the discourse of modern Islamic reforms that encourage moderate, inclusive, or progressive Islam. Instead

\footnotetext{
3 Pusat Pengkaian Islam dan Masyarakat (PPIM) UIN Syarif Hidayatullah Jakarta "Api dalam Sekam..., p. 6.

${ }^{4}$ Setara Institute, Survey Report, "Toleransi Siswa SMA ..., p.2.

${ }^{5}$ Pusat Pengkajian Islam dan Masyarakat (PPIM) UIN Syarif Hidayatullah Jakarta, "Api dalam Sekam PPIM, 2017... p.7, also see Dita Kirana, "Enhancing Religious Education: An Attempt to Counter Violent Extremism in Indonesia", Studia Islamika, Indonesian Journal for Islamic Studies, Vol. 25, No. 1, 2018, p. 200
} 
of becoming agents of peace or defenders of diversity in Indonesia, the younger generation of Muslims has non-tolerant thinking. Even more tragic is the source of such intolerant thoughts and attitudes from the teaching material of Islamic Religious Education formally developed by the country. Students who become PPIM surveys are the "results" of the Curriculum of 2013 developed by Indonesia. It is the official document of the country to direct educational outcomes in accordance with the ideals of the nation. The result of exclusively young Islamic generation can be expected to have space in the 2013 Curriculum for the emergence of an exclusive Islam that denies moderate or inclusive Islam.

The concept of inclusive Islam has long become the discourse in the scientific publication in Indonesia, namely the Islamic insight that can accept differences of belief/religion while embracing it as a different variant. The discourse begins with the statement of Nurcholis Madjid, dated 3 January 1970, which affirms "Islam Yes, No Islam Party" ${ }^{6}$, a statement to return to Islam and refuse to engage in New Order politics. This statement is quite controversial, because there is a belief that Islam is synonymous with practical politics, rejecting the Islamic party is similar to rejecting Islam. Therefore, Nurcholis Madjid proposed a number of supporting concepts such as secularization (and then encouraging Muslims to accept modernity). It continues to be an inclusive Islam, which is open to different religious beliefs and even believes that "Allah does not want human equality in all things. The difference becomes a motivation to compete for the good." "

The idea of Islamic Renewal has then provoked the emergence of other modern thinking, such as Abdurrahman Wahid, M. Dawam Rahardjo, Djohan Effendi, Ahmad Syafii Maarif, Kautsar Azhari Noer, Zainun Kamal, Musdah Mulia, M. Syafi'i Anwar, to a group of young thinkers such

${ }^{6}$ Taufik Abdullah, "40 Years of Islamic Renewal: Sebuah Ungkapan dan sekian Tantangan", presented in a scientific oration commemorating 40 Years of Islamic Reform in Indonesia, at Nurcholish Madjid Auditorium, Paramadina University campus Jakarta, January $7^{\text {th }}, 2010$, p. 2.

7 Budhi Munawar Rachman, Islam Pluralis, Wacana Kesetaraan Kaum Beriman, (Jakarta: Paramadina, 2001), p. 48 as Ulil Abshar-Abdalla, Abdul Moqsith Ghazali, and Budhi Munawar-Rachman. ${ }^{8}$ Unfortunately, Islamic reform thinking that embraces the foundation of the Pancasila State as "common Platform" (kalimatunsawa) is actually getting lost its supporters; the PPIM survey shows the symptoms.

The national curriculum is a product of the country, so there is great potential for the state (and its government) to disseminate ideology 9 . It formulates what is considered an important country for the younger generation to study, because it contains a choice of homogeneous knowledge, fixed values, and stable universal truths. Islamic thoughts of tolerating plurality should be the main material in the national curriculum, because Indonesia is a country that has a plurality of various aspects.

The results of PPIM surveys that show intolerance in the younger generation of Muslims indicate the possibility that inclusive Islamic discourse such as Nurcholis built is not a matter of Islamic Education course curriculum. If it doesn't contain inclusive thinking, it means that the ideology of the Indonesia requires intolerance. Another factor lies in the implementation of Islamic Education course that is still considered unsuccessful in working on the attitudes and behaviors of the learners and builds the moral and ethical of the nation. Two arguments are put forward to reinforce the statement, for example, the course is less able to convert cognitive religious knowledge into "meaning" and "value" or more emphasizes the knowing and doing aspect and has not yet led to the aspect of being; It has little relevance to social changes that occur in society or less illustrations of socio-cultural context ${ }^{10}$. There is also a criticism of the implementation of learning process that is only partial or just a mere memory that cannot

\footnotetext{
${ }^{8}$ Carool Kersten, Berebut Wacana Pergulatan Wacana Umat Islam Indonesia Era Reformasi, (Bandung: Mizan 2015), p. 23

9 Lyn Parker, Religious environmental education? The new school curriculum in Indonesia, Environmental Education Research, (Bandung: Mizan, 2016), p.2.

${ }^{10}$ Muhaimin, Rekonstruksi Pendidikan Islam Dari Paradigma Pengembangan, Manajemen Kelembagaan, Kurikulum hingga Strategi Pembelajaran (Jakarta: Raja Grafindo Perkasa, 2009), p. 30-31.
} 
reach up to the stage of religious attitudes in the face of contemporary problems ${ }^{11}$. Therefore, according to Amin Abdullah, Islamic education needs to find new breakthroughs so that content and methodology of Islamic Education course become actually contextual ${ }^{12}$.

This paper takes measurements on the material that has not implemented Islamic inclusivity in the curriculum. There is also a research by Lyn Parker (2016) but focused on the ecological content of religious education or Toto Suharto (2017) regarding the hidden curriculum not the official curriculum. He analyzed the PAI book conducted by Tien Rohmatin (2016) and PPIM (2016), but Rohmatin did not associate the textbook with the curriculum. Rohmatin focused more on various PAI teaching books printed and circulating in the community. Another thing, she used aids as her method, while this paper uses Critical Discourse Analysis. Nevertheless, the PPIM research is the basis of this paper, especially that the tolerance value in IRE textbooks for elementary schools to secondary schools is still ambiguous and contradictory "whereas" IRE textbooks are very important for the continuity of education in Indonesia. It would be very dangerous if religious textbooks contain violent content ". Based on it, this paper discusses inclusiveness in the 2013 curriculum and Islamic Education textbooks officially published by the country.

In order to build the purpose of writing, this paper begins with a general overview of Indonesia, then a review of literature on inclusive religions and curricula. Then after the information about the method used, put forward the results of research and discussion. At the end of the study are the conclusions, implications, and limits of research.

\section{Inclusive Islam and Curriculum}

Indonesia is the world's largest Muslimmajority country and the fourth largest country

"M. Amin Abdullah, "Perspektif Link and Match Lembaga Pendidikan Tinggi Tenaga Kependidikan Islam " presented at Muslih Usadan Aden Wijdan SZ, Pendidikan Islam dalam Peradaban Industrial (Yogyakarta: Aditya Media, 1997), p. 203.

${ }^{12} \mathrm{M}$. Amin Abdullah, "Problem Epistemologis Metodologis Pendidikan Islam", in Abdul Munir Mulkan, Religiusitas Iptek (Yogyakarta: Pustaka Pelajar, 1998), p. 52. in the world in terms of population. Over 300 ethnic groups and 700 living languages, it is one of the most culturally and linguistically diverse countries in the world. It is not a secular country or an Islamic state, but a royal state ${ }^{13}$. Being religious is normal, therefore in the public sphere, including schools, formal and informal events are opened with prayer; it has an important day in six officially recognized religions; villages, schools and communities receive state funds for the construction of mosques, temples and other places of worship. In the field of education, religious education is an inherent element and is very common at all levels of the school.

The existence of Islam as the majority does not run well. Islam as ideology constantly tries to dominate the implementation of the country, including the education system. On the other hand, there is a more substantive Islamic thought or cultural Islam. The struggle for discourse on Islamism and substantive Islam has influenced the content of the Religious Education curriculum. At the beginning of the reformation, the decentralization of the national education system was established, including the determination of the National Education curriculum. ${ }^{14}$ Starting in 2005-2006, namely after the issuance of the MUI fatwa concerning the prohibition of pluralism, liberalism, and secularism, the 2013 curriculum re-centralized was implemented. The centralistic Curriculum of 2013 can be influenced by the tension over this discourse. They can be identified in the determination of core religious or spiritual competencies that require all subjects to strengthen their religion and an indication of religious ideological pressure in the preparation of the 2013 Curriculum. The new Curriculum of 2013 is a revised-based competency model, or

${ }^{13}$ Yudhi Latif, Negara Paripurna: Historitas, Rasionalitas, Aktualitas Pancasila, (Jakarta: Gramedia,2011), p. 105.

${ }^{14}$ Carool Kersten, Berebut Wacana Pergulatan Wacana Umat Islam Indonesia Era Reformasi, (Bandung: Mizan, 2015) p. 23-27.Also see Fearnley- Sander, Mary, and Ella Yulaelawati. 2008. "Citizenship Discourse in the Context of Decentralisation: The Case of Indonesia." In Citizenship Curriculum in Asia and the Pacific, edited by L. David Grossman, W. O. Lee, and J.Kerry Kennedy, Hong Kong: Comparative Education Research Centre, University of Hong Kong.111-126; dan Raihani. 2007. "Education reforms in Indonesia in the Twenty-First Century." International Education Journal Vol. 8, No1, pp.172-183 
as a 'refinement' curriculum (Mendikbud, 2012 15 ), arguing that a fast-growing economy requires 'young people with entrepreneurial, strong, creative, resilient, honest and independent spirit' ${ }^{\prime 16}$.

The National Education Curriculum, thus, becomes the struggle arena for discourse between substantive Islam and Islamism. The curriculum is "a race course," or as "racing [men or horses] and one round in a racing course" ${ }^{\prime 7}$ The curriculum is considered to be an exercise track or course for learning, a course of study to be run, or a set of abilities given by students so that after graduation students have that ability. The curriculum has prescriptive aspects, plans $^{18}$ or teleological tendencies ${ }^{19}$ that are realized with a number of provisions for the realization of the plan. The ultimate goal is the goal of "The development of potential students to become human beings who believe and fear God Almighty, have noble character, are healthy, knowledgeable, capable, creative, independent, and become democratic and responsible citizens" ${ }^{20}$.

Giroux ${ }^{21}$ examined how curricula and other aspects of school benefit the dominant group and harm subordinates. The approach of this paper is essentially a critical pedagogy approach to inclusive religious education. Such approach not only encourages social criticism of the curriculum, but also seeks a transformation towards responsible religious education: education that critically examines the structure of religious

\footnotetext{
${ }^{15}$ Mendikbud (Kementerian Pendidikan dan Kebudayaan) [Ministry of Education and Culture]. 2012. Dokumen kurikulum 2013 [2013 Curriculum Document]. Jakarta, p.2

${ }^{16}$ Mendikbud (Kementerian Pendidikan dan Kebudayaan) ..., p. $7-8$

17 Ropo, E,. Identity and values in education. Published in Rabensteiner, P-M.\&Ropo, E. (Eds.).European Dimension in Education and Teaching, Vol. 2 2009, Schneider Verlag Hohengehren GmbH. (20-34), p. 25; Akker, J. van den. Curriculum Perspectives: An Introduction. In Curriculum Landscapes and Trends, J. van den Akker (eds.). Springer Science+Business Media Dordrecht, p. 2,2004; , Ellis Arthur K. Exemplars of Curriculum Theory. New York: Routledge,2013 p. 3.

${ }^{18}$ Ellis Arthur K, Exemplars of Curriculum Theory. (New York: Routledge,2013) p. 3.

${ }^{19}$ Null, W, Curriculum: from theory to practice.(Maryland: Rowman \& Littlefield Publishers, Inc, 2011), p.2.

${ }^{20}$ Undang-Undang Nomor 20 tahun 2003 tentang Sistem Pendidikan Nasional, Articlel 3.

${ }^{21}$ Henry A. Giroux,On Critical Pedagogy, (New York: Continuum, 2011). p. 67
}

differences, the interrelation between growing religious conflicts, non-harmonious interreligious relationships, and the need for an ethos of inclusiveness within religious.

Inclusive means open, refusing to exclusivism and absolutism ${ }^{22}$. Inclusive religion is a religious view, which assumes that things outside the religion they embrace also have the same truths from God. Inclusiveness is to believe all other religious truths exist in our religion. Inclusive theology is intended to provide an open, flexible, and tolerant understanding or insight ${ }^{23}$. Inclusive religion can be a womb for the birth of tolerance attitude by not giving a judgment and accusing others of being lost, let alone accusing the devil (kafir) 24 ; on the contrary, it can be argued that non-tolerant attitudes or thoughts stem from exclusive religions. Religious inclusiveness means religion that is humble, open, broad and critical, enriching the insights of knowledge and religious experience and closer to the path of truth ${ }^{25}$.

In Indonesia, the idea of religious inclusiveness is developed by Nurcholis Madjid who distinguishes people and the common Islamic religion (non-Muslim par-excellence), and Muslim par-excellence ${ }^{26}$. According to him, Islam as a religion is not monopolized and only for the followers of Muhammad Saw, Islam is universal especially because Islam is attitude and surrender, submissive to God. The Mighty Creator that anyone can have ${ }^{27}$.

All religions, for him, rest on a "common ground", or in terms of the Quran kalimahsawâ $\hat{a}^{28}$, it means faith and good action ${ }^{29}$. Therefore, the standard of salvation in religion is faith and

${ }^{22}$ Ahmad Amir Aziz, Neo Moderenisme Islam di Indonesia, (Jakarta: PT. Rikeka Cipta, 1999), p. 27.

23 Zainal Abidin, "Teologi Inklusif Nurcholish Madjid; Harmonisasi antara Keislaman, Keindonesiaan, dan Kemoderenan" in Jurnal Humaniora, Vol. 5 No. 2, Oktober 2014, p. 682

${ }^{24}$ Abdul RohimGhozali, Atas Nama Agama, (Bandung: Pustaka Hidayah, 1998), p. 53.

${ }^{25}$ Komaruddin Hidayat and Ahmad Gaus, Passing Over, Melintasi Batas Agama,( Jakarta: Gramedia, 1999), p. 47.

26 Budhy Munawar-Rachman, Islam Pluralis, Wacana Kesetaraan Kaum Beriman,(Jakarta: Paramadina, 2001),p. 35

${ }^{27}$ Nurcholish Madjid, Islam Agama Kemanusiaan, (Jakarta: Paramadina, 1990), p. 10.

28 Al-Qur'an: 3: 64

${ }^{29}$ Sukidi, Teologi Inklusif Cak Nur, (Jakarta: Kompas, 2001), p. 36. 
good deeds. True faith, for Madjid, establishes consciousness as fellow human beings and fellow creatures will cultivate mutual respect, and form social relations that remind each other of truth, without wanting to impose their own stance ${ }^{30}$. The importance of resignation attitude can be said that religion without resignation to $\mathrm{God}^{31}$, although he adheres to "Islam", is not true and "will not be accepted" with God, although he is a Muslim but not submissive and surrender to God, losers in the hereafter ${ }^{32}$. He refers to two facts of Islamic history, namely the Charter of Medina ${ }^{33}$ and Khutbah Wadâ'. ${ }^{34}$

\section{Method}

This study employed library research that seeks to examine the value of religious inclusiveness in the 2013 curriculum and religious education textbooks that are officially published by the state. The primary data sources examined in this study were high school curriculum (Mendikbud, 2013), 35 policy documents (Mendikbud, 2012) ${ }^{36}$, and Islamic Education textbooks for students and teachers. ${ }^{37}$ The secondary data were Catholic Education textbook. The method used in this study was critical discourse analysis.

Educational scholars have identified a variety of techniques to analyze the curriculum critically, including with the use of Critical Discourse Analysis (CDA) tools. This paper analyzed the 2013 curriculum using critical discourse analysis

\footnotetext{
30 Nurcholish Madjid, Islam Doktrin dan Peradaban, (Jakarta: Paramadina, 1995), p. 126.

${ }^{31}$ Sukidi, Teologi Inklusif.., p. 21.

${ }^{32}$ Sukidi, Teologi Inklusif.., pp. 21-22.

33 Adi Suryadi Culla, Masyarakat Madani: Pemikiran, Teori, dan Relevansinya dengan Cita-cita Reformasi (Jakarta: Rajagrafindo Persada, 1999), p. 193. Also see A. Ubaedillah dan Abdul Rozak, Pendidikan Kewarganegaraan (Civic Education): Demokrasi, Hak Asasi Manusia, dan Masyarakat Madani, Cet. III (Jakarta: Prenadamedia Group, 2013), p. 223; and Budhy Munawar Rachman, Ensiklopedi Nurcholis Madjid,(Jakarta: Paramadina, 2006), p. 2298

34 Budhy Munawar Rachman, Ensiklopedi..., p. 2680

35 Peraturan Menteri Pendidikan dan Kebudayaan No. 69 Tahun 2013 tentang Kerangka Dasar dan Struktur Kurikulum Sekolah Menengah Atas/Madrasah Aliyah

${ }^{36}$ Peraturan Menteri Pendidikan dan Kebudayaan Nomor 71 Tahun 2013 tentang Buku Teks pelajaran dan Buku Panduan Guru untuk Pendidikan Dasar dan Menengah

${ }^{37}$ Kemendikbud, Pendidikan Agama Islam dan Budi Pekerti Untuk SMA/MA/SMK/MAK Kelas X, 2014,
}

proposed by Fairclough ${ }^{38}$. CDA is a way of studying the relationship between language, society, and power. It can be used to find the connection between phenomena in the text, for example when students learn 'tolerance', does the curriculum identify agents - who or what creates violence and who is the agent of tolerance? CDA studies the dialectical relationship between discourse and phenomena, and between the internal and external meanings of discourse. It is interesting to look for an explanation of the causes and implications of phenomena in the curriculum. Fairclough focuses on the constructive function of the language, for which special and repetitive language can have a discursive effect that is what the original learning is not true.

Norman Fairclough argues that discourse is a social practice and divides discourse analysis into three dimensions: text, discourse practice, and social practice. Text is analyzed in textual or microstructural with the assumption that each text simultaneously has three functions, namely representation, relation, and identity. The texts at this stage are considered to represent, relate, and raise the identity of social reality. Fairclough marks all of it as linguistic analysis, i.e. cohesion analysis and coherence text, grammar, text thematic structure, and diction or keywords that appear in the text. The second stage, the analysis of the dimension of discrimination (Mesostructural) is conducted on the process of discourse covering aspects of production, dissemination and use of text. The third dimension is the analysis of socio-cultural practices (Macrostructural) is a macro-level analysis based on the opinion that the social context that exists outside the text actually influences how the existing discourse exists in the text. Socio-cultural practice analyzes three things: economics, politics (especially with regard to issues of power and ideology) and culture (especially with regard to values and identity).

38 Norman Fairclough, Critical Discourse Analysis: The Critical Study of Language, Electronic book, revised 2nd ed. Old Tappan: Taylor and Francis, 2013. 


\section{Discourse of Religious Inclusiveness in the 2013 Curriculum and Textbooks}

The focus of this research was to find the discourse of religious inclusiveness in the 2013 curriculum and textbooks (students and teachers) by using CDA approach. Following the Fairclough CDA method, this paper presented the results of the study in three parts, namely text analysis, discourse practice, and social practice.

\section{Text Analysis of the 2013 Curriculum of Islamic Education Course Textbook}

The 2013 Curriculum formulates the Core Competencies and Basic Competencies that serve as guidelines for teachers in implementing the learning process. In addition, these two competencies serve as a benchmark in textbook writing. There are four core competencies, which are then translated into more operational ones into basic competencies, i.e. religious or spiritual, social, cognitive, and practical or behavioral competencies. The theme of religious inclusiveness is included in the core social competence, for that in the early stages of text analysis of basic competency loads derived from the core competencies of social attitudes.

The 2013 Curriculum for Islamic Education course in high school contains basic competencies on tolerance and social behavior as a derivative of core competence: "showing honest, discipline, responsible, caring, responsive, honest, and pro-active as part of the solution to various problems in interacting effectively with the social and natural environment and placing self as a reflection of the nation in the association of the world" 39 . The core competency explores a number of other competencies that become the benchmark of learning for teachers as follows:

39 Permendikbud Number 024, 2016, Appendix 40
Table 1: Competence of Tolerance in the 2013 Curriculum

CORE COMPETENCE 2 (SOCIAL ATTITUDE)

2. Demonstrate honest, discipline, responsible, caring (cooperative, tolerant, peaceful) behavior, polite, responsive, and pro-active as part of the solution to problems in interacting effectively with the social and natural environment and placing self as a reflection of the nation in the association of the world

\begin{tabular}{ll}
\hline GRADE & BASIC COMPETENCIES \\
\hline $\mathrm{X}$ Grade & $\begin{array}{l}\text { 2.11 Showing the spirit of ukhuwah and harmony } \\
\text { as the emblem of the history of propagation } \\
\text { strategy of the Prophet in Medina }\end{array}$
\end{tabular}

XI Grade $\quad 2.2$ Being tolerant, harmonious, and avoid violent acts as the implementation of understanding Q.S. Yunus / 10: 40-41 and Q.S. al-Maidah / 5: 32, and related Hadith

2.10 Being in harmony and competitive in goodness as the implementation of the values of the development of Islamic civilization in the heyday

2.11 Being harmonious and competitive in goodness as an implementation of the historical values of Islamic civilization in modern times

XII Grade $\quad 2.1$ Being critical and democratic according to Q.S. Ali Imran / 3: 190-191 and 159, and hadith-related

2.2 Performing good deeds to others in accordance with Q.S. Luqman / 31: 13-14 and Q.S. al-Baqarah / 2: 83, and related hadith.

2.9 Upholding harmony and peace in everyday life

2.10 Upholds the values of Islam rahmatanlilalamin as a trigger of the progress of Islamic civilization in the future

Source: tracking results

Table 1 shows the social behavior specifications of the 2013 Curriculum for Islamic Education course in high school students that include ukhuwwah and harmony (in X grade); tolerant, avoiding the act of violence, being harmonious and competitive in goodness (in XI grade); and being critical and democratic, performing good deeds to human beings, upholding harmony, and being peaceful in everyday life, as well as upholding high values of rahmatanlilalamin. The focus of this study was ukhuwwah, harmony, tolerances, anti-violence, attitude, critical and democratic. All themes are included in an inclusive religious sphere.

Based on the provisions of the competencies, it set forth in the curriculum of 2013 formulated textbooks. In the textbook published by Kemendikbud, there are several chapters 
presented to build those attitudes, namely lesson 10 "Examine the Propagation Struggle of the Prophet in Medina" (X Grade), lesson 11 "Tolerance as the National Unifying Tool" (XI grade), and the 14th lesson "Unite in Diversity and Democracy" (XII grade). These three chapters are the implementation of basic competencies in the form of teaching materials for students and teaching materials for teachers.

The Islamic Education course textbook is built on the same framework. Each lesson is structured into 6 sections, "opening the hearts", "criticizing our surroundings", "enriching the treasures", "applying noble behavior", "summary", and "evaluation". The first part is to open the "heart of the heart" with the reflection that awakens the personal consciousness of the students. The "criticizing around us" section is a reflective text based on social phenomena built as an extension after self-reflection, and then the core matter taught is expressed in the "treasures ". In the section "applying noble behavior", it puts forward conclusions that lead to character formation, while material conclusions are put forward in the "summary".

The analysis will be carried out in all sections of the chapter containing the theme of religious clarity, i.e. lesson 10 in the $X$ grade, and lesson 11 for XI grade. While the 14th lesson in XII grade that talks about democracy will not be discussed, because the description does not directly talk about tolerance.

\section{a. Attitude of Ukhuwwah}

This lesson opens with the "Opening of the Heart" which emphasizes the importance of building an ideal environment for the growth of life as "The environment has a profound influence on one's person and behavior". ${ }^{40}$ This section is an introduction to the importance of the character of keeping ukhuwwah, not only raising the character but also striving for it. Rasulullah SAW teaches how believers should demonstrate attitudes in order to not go astray of the surrounding environment. He is even required to be part of a

40 Kemendikbud, Pendidikan Agama Islam dan Budi Pekerti...,p 148. positive change for his environment. It requires intelligent efforts to achieve maximum results ${ }^{41}$.

The "Criticizing around Us" section expressing the fate of minority Muslims in Rohingya is oppressed by the syntax of religion. The Rohingya Muslim case becomes an entry point to express the importance of ukhuwwah or brotherhood, as put forward in the following persuasive sentence "The suffering of Muslim Rohingyas should be of concern to us all as fellow Muslims. They deserve help to be able to live freely and independently, especially to be independent in worshiping Allah Swt " ${ }^{42}$. As this phrase emphasized in the "fellow Muslim", so ukhuwwah is limited to fellow Muslims. This description ends with a call that further limits the meaning of ukhuwwah, as in the phrase: "Let us meditate clearly so that our brothers and sisters can live safely and peacefully" 43 .

The core material is presented in the section "Enriching Khazanah Learners" which contains 3 materials, namely understanding the struggle Propaganda of the Prophet Muhammad ${ }^{44}$, The substance and Propagation of the Prophet in Medina ${ }^{45}$, and the Propagation Strategy of the Prophet in Medina ${ }^{46}$. In the first matter, the Quraish infidels pressed on the Prophet who made the trigger of the Prophet's and his Companions' migration to Medina. The second part, the substance and propagation of the Prophet in Madinah was fostering the brotherhood between the Ansar and the Muhajirin, forming a society based on the teachings of Islam, and teaching political, economic, and social education. This book restricts ukhuwah or brotherhood to Muslims only, the Ansar and the Muhajirin. A peaceful relation with a non-Muslim party is put forward as an in-agreement relation, as in

\footnotetext{
${ }^{41}$ Kemendikbud, Pendidikan Agama Islam dan Budi Pekerti..., p. 148.

42 Kemendikbud, Pendidikan Agama Islam dan Budi Pekerti..., p, 149.

43 Kemendikbud, Pendidikan Agama Islam dan Budi Pekerti..., p. 149.

44 Kemendikbud, Pendidikan Agama Islam dan Budi Pekerti...,p. 150-151.

45 Kemendikbud, Pendidikan Agama Islam dan Budi Pekerti...,p.151-154.

46 Kemendikbud, Pendidikan Agama Islam dan Budi Pekerti...,p.154-159.
} 
the phrase: "The Prophet Saw in creating an atmosphere of comfort and calm in the city of Medina, a treaty with the Jews was made. In the treaty it is established, and it is recognized the right of liberty of every group to embrace and practice its religion" 4 .

The core material on "Shaping Islamic Society" contains religious freedom, prayer, alms (zakah), and fasting, then the humanitarian principles of the Prophet's final sermon on Haji Wada (year $10 \mathrm{H} / 631 \mathrm{M}$ ). The Islamic Society, therefore, is a society that provides religious freedom on the basis of humanitarian principles, including giving Muslims freedom for prayer, alms (zakah), and fasting. This book confirms the two purposes of teachings that the Prophet brought, "to give peace to his followers," and "to grant freedom to Muslims, Jews and Christians in their respective religious beliefs" 48 . Freedom for non-Muslims is expanded to include freedom of expression, freedom of worshipping according to his religion, and freedom to preach his religion ${ }^{49}$. Freedom is portrayed as the guarantor of attaining righteousness. Opposing it means strengthening evil and eroding the light of truth.

The contents of the last sermon of the Holy Prophet as "principles of humanity" are presented in detail. The contents of the last sermon are: the prohibition of shedding blood except with haq and the prohibition of taking other people's treasures with vanity because life and possessions are sacred; the prohibition of usury and the prohibition of persecution, the command to treat wives with kindness and gentleness and commandment away from sin; forgiving all the quarrels between them in the age of ignorance; the unwarranted behavior of revenge, brotherhood and equality among men should be upheld; treats the servant well, and must always hold on to the Quran and the Sunnah. ${ }^{50}$

\footnotetext{
47 Kemendikbud, Pendidikan Agama Islam dan Budi Pekerti..., p.152.

48 Kemendikbud, Pendidikan Agama Islam dan Budi Pekerti..., p.153.

49 Kemendikbud, Pendidikan Agama Islam dan Budi Pekerti...,p.153.

5o Kemendikbud, Pendidikan Agama Islam dan Budi Pekerti...,p.154
}

This closing paragraph of the "humanitarian messages" section does not provide clarification of what human messages are, how they relate to the last orders of the last sermon with humanitarian messages. The author included this farewell speech material as a mere historical fact, not as a foothold for building tolerant behavior for students in their lives.

The last part of the core matter is "The Propagation Strategy of the Prophet in Medina" which contains material laying the foundations of social life, the Prophet's letter to the Kings, and the Conquest of Mecca. The basics of social life in this section are to build mosques, to build ukhuwwah Islamiyah, and to make friends with other non-Muslim parties. There is the use of a different word between the Muslims, namely ukhuwwah, with the non-Muslims, i.e. friendship. There is an indication of the distinguished meaning of ukhuwwah and friendship. Ukhuwwah is the brotherhood of fellow Muslims, while friendship is a peaceful relationship with the Muslims "in order to maintain stability" with "the Prophet Muhammad as he became head of government and absolute authority is left to him ". .51

The last part of this chapter is "Applying the Noble Behavior" which expresses the meaning of ukhuwwah. The Islamic Education course textbook defines ukhuwwah as a brotherhood, and as "a relationship among people that is bound by something". It is expressed the types of ukhuwwah on the basis of "something" that binds it, "In this context, we recognize family, tribal, national, religious, and humanitarian brotherhood. The special brotherhood of Islam is called ukhuwwah Islamiyah ". ${ }^{52} \mathrm{It}$ is a fraternity in the name of equality. Therefore there is a national brotherhood because of living in one nation. There is no brotherhood with different believers unless "friendship" in the covenant.

This passage also sets forth the basic principle of coexistence, that "no one in this world is capable of meeting his needs by his own ability. Thus, everyone is very dependent on

\footnotetext{
51 Kemendikbud, Pendidikan Agama Islam dan Budi Pekerti..., p.155.

52 Kemendikbud, Pendidikan Agama Islam dan Budi Pekerti..., p.160.
} 
others. To be able to eat a plate of rice with side dishes, someone needs farmers, fishermen, and plate makers, drivers to transport food materials, porters, traders, and so forth. Therefore, human relations are a necessity or a certainty that no one should ignore. "Then at the end of this sub-section is put forward". Brotherhood means to abolish or eliminate hostility. Hostility is a disgraceful attitude that incurs many losses".

The basis of the need to establish ukhuwwah or brotherhood is the rational-pragmatic and historical importance of Prophet's behavior in Medina. There is no Quran or hadith texts mentioned in Lesson 10. It may be part of the History of Islamic Civilization, one of the four core materials of Islamic Education course, namely Akidah Akhlak, the Quran-Hadith, Figh, and History of Islamic Culture.

\section{b. Tolerance, Harmony, and Avoidance of Violence}

This material is presented in XI grade in the last lesson, with the title "Tolerance as a National Unifying Tool". It presents two main themes, namely tolerance and avoidance of violence. The lesson description opens with the "Opening of the Heart" section that elicits writing that encourages students' awareness of the importance of maintaining tolerance. It begins with the phrase "One of the great agenda in the life of nation and state is to maintain unity of the Unitary Country of the Republic of Indonesia (NKRI). The challenge is the issue of religion and nation harmony. Internal, interreligious, and interreligious harmony with the government, ${ }^{53}$ while asserting that high school students as educated should actively participate in maintaining the integrity of the nation, harmony in social life" 54 . This passage includes a hadith about "not believing a servant so that he loves his neighbor as he loves himself".

The second part "Criticizes around Us" presents events of intolerance and violence that disturb and threaten the integration of the nation. The violence displayed is not only interreligious

\footnotetext{
53 Kemendikbud, Pendidikan Agama Islam dan Budi Pekerti..., p.186.

54 Kemendikbud, Pendidikan Agama Islam dan Budi Pekerti..., p.186
}

violence, but also brawl. It also expresses the tolerant behavior of Muslims welcoming Idul Fitri with warmth and forgiving each other. ${ }^{55}$ Thus description closes with the question "How would you respond if the atmosphere took place all the time?" 56

Tolerance defines this book as "respecting and learning from others, respecting differences, bridging the gap among us so as to achieve common attitudes". ${ }^{57}$ It is asserted that tolerance is "the beginning of accepting difference, a distinction must be appreciated and understood as wealth"..$^{8}$ It is to put forward two verses of the Quran, i.e. Q.S Yunus [10] verse 40-41. The first verse suggests that the difference of faith is a natural thing. The preaching differences exist. The second verse suggests an attitude that should be addressed to a non-believer, namely "to me my job, and for you yours, you are detached from what I do and I disregard what you do "(lî 'amalî walakum' amalukum, antum barî-una a'malu wa anâ bari-u mimma ta'malûn). The conclusion is "the believer must be firm in his belief and live among people of different faiths with him"59 and the method of respecting difference and tolerance, i.e." not disturbing the religious activities of others".

There is a difference in the orientation of the meaning of tolerance between the proposed definition and the referenced verse. On the definition, tolerance is the attitude of "respecting and learning from others, respecting differences, bridging the gap." On the other hand, the verse interpreted tolerance as "firm stance on his beliefs despite living in the midst of people of different faiths" and "does not interfere with other's religious activity." The interpretation of the verse does not support the emergence of tolerance such as the definition of "respecting and learning from others, respecting differences, bridging gaps or differences."

\footnotetext{
55 Kemendikbud, Pendidikan Agama Islam dan Budi Pekerti..., p.187.

56 Kemendikbud, Pendidikan Agama Islam dan Budi Pekerti..., p.187.

57 Kemendikbud, Pendidikan Agama Islam dan Budi Pekerti..., p.188.

58 Kemendikbud, Pendidikan Agama Islam dan Budi Pekerti..., p.188.

59 Kemendikbud, Pendidikan Agama Islam dan Budi Pekerti.., p 191.
} 
The hadith quoted as complementary to the interpretation of the verse reveals the "best" glory of the man to his fellow brothers and neighbors. It is to support the definition of tolerance, but does not explore further as in "How to appreciate difference and tolerance among others, not to interfere other's religious activities". The exploration of tolerance is shown on "Applying the Noble Behavior", which lists the importance of mutual respect for the differences of beliefs, "in the form of" not to impose other's will to follow our beliefs, "to people of different religions emphasize to show noble behavior, God willing, others will be interested "

The second subject of this lesson is "Avoiding the Violent Behavior". This section is built with the theoretical descriptions of hatred and love, that love and hate (then friendship and enmity) are products of the passion that God has given to human. Lust can make them achieve perfection or misery. It is affirmed, "Only lust which has been successfully tamed by reason will be able to deliver man to perfection. On the contrary was if lust beyond the control of reason, necessarily plunges man into the abyss of misery and disgrace" ${ }^{61}$. It emphasizes that "Islam forbids the conduct of violence against anyone" as quoted in Q. S. al-Māidah [5]: 32, which states God's stipulation that "he who kills a person, not because that person kills another person (qisash), or not because of corruption on earth, it is as if he has killed all humans. Whoever preserves the life of a man, it is as if he has preserved the life of all".

The violence in this book is associated with "murder", the act of nonviolence is the protection of the human soul. In the early part of the concept of the nafs that contains the potential of love and hate, violence is associated with hostility. This violence as "killing" is reinforced when this book suggests three lessons that can be picked up by Q.S al-Māidah [5]: 32. However, there is an ambiguous attitude expressed about murder, "The value of a work is related to their

\footnotetext{
60 Kemendikbud, Pendidikan Agama Islam dan Budi Pekerti..., p.196

61 Kemendikbud, Pendidikan Agama Islam dan Budi Pekerti..., p.192.
}

purpose, personal murder with malicious intent is the annihilation of a society, the court to execute a murderer in the framework of qisash is the source of community life "62. In other words, not every murder is violence, or an act called violence depends on intent.

The definition of violence other than as "murder" is put forward in other parts, behaviors that can harm others, including hurting and committing acts of violence against them ".${ }^{63} \mathrm{In}$ the section "Applying the Noble Behavior", it is put forward the necessity of empathy as the seed of nonviolence, "When it comes to harassing others, it must be aware that harassing it will be painful, what if it happens to us" ${ }^{64}$. As an affirmative of this lesson stated "Our joint duty is to keep the peace of life by loving the neighbors. ${ }^{65}$

There is one interesting quotes in this book, the story of Ali bin Abi Talib who was late to conduct congregation prayer for appreciating an old man who blocked his way. The award of Ali bin Abi Talib made the Prophet Muhammad who was then the imam commanded by Gabriel to slow down his prayers, when the Prophet Muhammad asked what the reason was, Gabriel explained, "O Muhammad, Ali was hasty to carry out the congregation, but on the way, there is a grandfather and he does not want to precede him because it is very respectful of others, even though he is Christian ". Unfortunately, this section was not explored further.

\section{Discourse Practice Analysis of the 2013 Curriculum of Islamic Education Course Textbook}

The 2013 curriculum and textbooks are created by the country or at least it controls. The textbook is compiled by the author selected after a number of authors submitted book proposals based on the competencies set in the

\footnotetext{
${ }_{62}$ Kemendikbud, Pendidikan Agama Islam dan Budi Pekerti..., p.195

63 Kemendikbud, Pendidikan Agama Islam dan Budi Pekerti..., p. 195

64 Kemendikbud, Pendidikan Agama Islam dan Budi Pekerti..., p.196

65 Kemendikbud, Pendidikan Agama Islam dan Budi Pekerti...,p. 195.
} 
2013 curriculum. The selected authors then write the book under the supervision of the Book Curriculum Center, the Research and Development Board (Balitbang), the Ministry of Education and Culture (Kemendikbud). It is visible on the start page of Islamic Education course's student and teacher books.

Contributor: Mustakim and Mustahdi. Reviewer: Muh. Saerozi and Yusuf A. Hasan. Supervisor Publishing: Central Curriculum Book keeping, Balitbang, Kemdikbud. ${ }^{66}$

There are three parties who became the producers of this textbook, namely the Selected manuscripts based on the selected proposal (not employees of Kemendikbud), then the review of the manuscript and supervisor of the publication of the Curriculum Center. There is no explanation as to who the contributor of this manuscript, Mustakim and Mustahdi's identity are not mentioned, they could be representatives of religious organizations such as Nahdhatul Ulama (NU) and Muhammadiyah or he is Islamic intellectual from Islamic university or author who has no affiliation. However, the ministry published it officially and the author's name is not included on the front cover. It is understandable that they are representatives of the ministries of education and culture.

Different things are found in the author of the book Catholic Religious Education. The course textbooks are published by Kemendikbud, but book manufacturers have different arrangements:

Screen Contributors: YennySuria and Susi

Bonardy.

NihilObstat: F.X. Adisusanto, S.J. February

22, 2013

Imprimatur: Mgr. John Liku There '27

February 2013

Reviewer: F.X. Adisusanto, S.J. and

MatheusBeny Mite.

Supervisor Publishing: State Polytechnic

Creative Media, Jakarta ${ }^{67}$

There are two different agents on the author of it, namely Nihil Obstat and Imprimatur. Both of these agents turned out to be related to the

${ }^{66}$ Kemendikbud, Pendidikan Agama Islam dan Budi Pekerti..., Book 2

${ }^{67}$ Kemendikbud, BukuPendidikan Agama Katolik, 2015, p.2
KWI Catechetical Commission (the Indonesian Bishops' Conference $)^{68}$. Referring to Wikipedia, "Katekese word (catechesis) means mouth-tomouth instruction, especially in the form of question and answer. Although it may apply to any subject-matter, and is usually used for instruction in religious elements, especially preparation for initiation into Catholicism" ${ }^{69}$.

\section{Social Practice Analysis of the 2013 Curriculum of Islamic Education Textbook}

This section discusses some text related to social conditions of Indonesia as the context of the 2013 Curriculum. Tolerance and violence against other religions have a clear context in Indonesian daily life, such as violence against Ahmadiyah, church bombing, and violence against ethnic Chinese in 1998. It is not mentioned in textbooks. Instead of presenting the social context in Indonesia, Islamic Education course book shows the fate of minority Muslims in the oppressed Rohingyas due to religious syndrome, with the call "The Suffering of Muslim Rohingya should be the concern of all of us as Muslim brothers". The obscured Indonesian social context shows a lack of seriousness in building tolerance.

In the description of tolerance, the call for tolerance is expressed "on religion" without a clear address, and it doesn't give the opportunity of normative conceptual interpretation. It is different from the course book of Catholic Education and Character which provides a lesson on "Dialogue and Cooperation among Interfaith People", in grade XII. In the lesson, the material "Knowing More About Other Religions" contains the main points in the teachings of religion $X$, $X$ 's religious attitude towards other religions, religious festivals $X$, and the description of the Catholic Church's View of Religion X.

The Catholic Education textbook, for example, introduces an early introduction to the teachings of Islam in the sub-chapter "Knowing More about Islam" ${ }^{\circ}$. The chapter includes a statement that

\footnotetext{
68 https://en.wikipedia.org/wiki/Conference_Waligitab_ Indonesia accessed on 13 November 2018.

69 https://en.wikipedia.org/wiki/Katekese accessed on 13 November 2018.

70 Kemendikbud, PAK Book, 2015, pp. 115-121.
} 
in relation to other religions, Islam has a high tolerance (Q.S al-Baqarah [2]: 62 and al-Maidah [5]: 83). Al-Baqarah [2]: 62 is a verse commonly proposed by Nurcholis Madjid, but they are not used in Islamic Education textbooks. The verse asserts that, "Indeed people the faithful and the Jews and the Christians and the Shobinites are the ones who believe in Allah, the Day of Judgment and the good deeds they are rewarded with their Lord, and there is no fear for them nor their hearts". On the other hand, al-Maidah [5]: 83 expresses the respect of Islam to the Christians, described as "the closest of his affection to the believers”.

The Catholic Education textbook also appreciates the Quranic verses that affirm the principle of "no compulsion in religion", and suggests that Prophet Muhammad has given many examples of how he respects and loves people of other faiths. Furthermore, the book suggests how the Quran mentions various figures from the Old Testament, such as Isa, and Maryam. Isa is described as "a special prophet, born through a miracle. He is also blessed, holy, pure, the apostle of God, the way of the righteous, the mediator, even called the Sentence of God and the Spirit of God. However, He is not God ".71

The description of Islamic teaching ends with the official Catholic attitude to Islam. It contains the affirmation that "the Church also respects Muslims"72, putting forward some reasons underlying that respect. First, Islam preaches worship and obedience to God in a monotheist manner as Abraham had committed himself to God. Secondly, the Islamic teachings, although not recognizing Jesus as God, but honoring Him as the Prophet, also honoring Mary His Mother who remains virgin. Third, Islamic teachings trust and crave the Day of Judgment. Fourth, Muslims uphold the moral life, and worship to God especially in prayer, by giving alms and fasting. The historical facts of the Catholic-Islamic encounter are expressed:

"Namun demikian tidak dapat dipungkiri disepanjang zaman cukup sering timbul pertikaian dan permusuhan antara umat

\footnotetext{
${ }^{71}$ Kemendikbud, PAK Book.., p. 120.

${ }^{72}$ Kemendikbud, PAK Book..., p.120.
}

Kristiani dan kaum Muslimin. Konsiliasi suci mendorong agar melupakan peristiwa yang sudah berlalu, dan dengan tulus hati melatih diri untuk saling memahami; bersama-sama membela serta mengembangkan keadilan social bagi semua orang, menghormati nilai-nilai moral maupun perdamaian dan kebebasan"73

\section{Meaning:}

However, it cannot be denied that throughout the ages, it somewhat often arises conflict between the christians and muslims. Holy conciliation encourages forgetting events that have passed, and sincerely trains themselves to understand each other; jointly defend and develop social justice for all people, respect moral values and peace and freedom.

The Islamic Education textbook shows inconsistency in concept-building and the use of material resources. The concept of brotherhood is built ambiguously among brotherhoods based on similarity with friendship-in-agreements. The concept of tolerance is built unclear. Violence is interpreted only as murder, a murder can be allowed depending on the load. The definition of tolerance is even expressed unusually, as "respecting differences and learning from others, bridging the gap between us so as to achieve common attitudes". The existence of the purpose "in order to attain the same attitude" is not found in other definitions of tolerance. For example, the Declaration of the Principles of Tolerance of UNESCO states that tolerance is the respect, acceptance, and appreciation of the rich cultural diversity of the world, the various forms of self-expression, and the ways of being human. Tolerance is harmony in difference ${ }^{74}$.

In addition, the most interesting factor is the presence of producers between Islamic Education textbook and Catholic Education textbook. Muslim personal scientists write Islamic Education book without any association with the official Islamic institution, while Catholic Education book is written by the catechetical commission. This suggests that on the preparation of Catholic

\footnotetext{
${ }^{73}$ Kemendikbud, PAK Book..., p.121.

${ }^{74}$ Akhsanul Khalikin and Fathuri (ed), Toleransi Beragama di Daerah Rawan Konflik, (Jakarta: Puslitbang Kehidupan Keagamaan, 2016), p. 12.
} 
Education textbook, the Ministry of Education and Culture collaborates or involves the official Catholic institution in Indonesia. On the other hand, the Ministry did not involve any Islamic official institution in the preparation of Islamic Education textbook.

Moreover, the meaning of Obstat and Imprimatur Nil is not an ordinary editor as it is in the writing of a book. Nihilobstat means "no apostasy". An official statement from a particular party said that the text is safe to submit to the Bishop to be examined so that the bishop can make a decision. The imprimatur (official permission to publish a book ${ }^{75}$ ) is an official decree or declaration of the bishop that the book submitted via nihilobstat is free of doctrinal error and has been approved for publication after a careful the examination ${ }^{76}$. Nihilobstat and Imprimatur are two concepts related to the magisterium, namely the authority to teach the Church to "protect the people against errors and weaknesses of the faith and guarantee for them the objective possibility, to recognize the original faith, free from error". The Catholic Education textbook, therefore, was published by Kemendikbud after obtaining the permission and approval of the bishops' Megisterium in Indonesia, while Islamic Education textbook did not obtain permission from the official Islamic organization in Indonesia.

\section{The Discourses of Inclusivism in 2013 Curriculum on Islamic and Catholic Education}

These are shown in two different approaches. These differences indicate the theological orientation from both religions. Islam has made some experts on liberalism perspective such as the works of Nurcholis Madjid, Abdurrachman Wahid, and etc. In fact, their works never gave influence on the production of Islamic Education

75 https://dictionary.cambridge.org/dictionary/english/ imprimatur accessed in February 2018,

76 Straight Answers: The Magisterium's 'Imprimatur"' "Imprimatur"' by Fr. William P. Saunders; Arlington Catholic Herald, Inc; Copyright 01999 Arlington Catholic Herald, Inc. All rights reserved; www.catholicherald.com," translated by YESAYA: www.indocell.net/yesaya with permission from The Arlington Catholic Herald."accessed July 25, 2017 textbook. On the contrary, Catholic religion in Indonesia, even though they don't produce the works of inclusivism discourse, they have put the ideology of inclusivism on their Catholic Education textbook. The first approach is Islamic education. It never gave an admission to the existence of other religion. The construct of Nurcholis Madjid that recognizes non-Muslim as Muslim does not appear. Inclusivism is presented in the form of construct through the existence of non-Muslim. For instance, democratic, tolerance and brotherhood discourse have existed on the acceptance of differences. This approach indirectly accepts inclusiveness by not mentioning the existence of any other religion.

The second approach by the Catholic view gives different knowledge on other religion in Indonesia. In addition, Catholic Education textbook revealed the meetings and the truth of the history of non-Catholic religions. The inclusion of the history of conflicting religions on their works is one of the strategies of limited inclusivism discourse, or cautious inclusivism. Even so, what the Catholic Education book has as its basic knowledge in different religions can be the role model for any other religious teaching book.

There are two different interesting topics to discuss as the enforcer of the aforementioned findings, namely the question of producers and the struggle for discourse in the 2013 Curriculum. First, the different in producers can mean that the material of Islamic Education book is not the will of the Islamic religious institutions (such as Nahdlatul Ulama and Muhammadiyah) and not the true teachings of Islam, but the author's construct (legitimized by Kemendikbud) on Islamic teachings. When referring to the history of Indonesian Islamic Intellectuals proposed by Carool Kersten, the tendency that does not involve Islamic religious organizations began in the early days of the New Order government. The affairs of Islamic religious development, at that time, were given to individuals or bureaucrats in the ministry. The trend is still maintained until the reform era.

Secondly, there are two discourses appeared in the two lessons above namely "freedom" (Islamic Education textbook for $\mathrm{X}$ grade) and "reason as the controller of lust" (Islamic 
Education textbook for XI grade) on one side and on the other side about qisash. Freedom discourages as a source of truth, and it creates the relationship of love and unity or ukhuwah. There is an argument built that out of freedom that gives birth to ukhuwwah (brotherhood or attitude harmonious). In grade XI book, it is argued that the not-heart-mind became the determinant of the orientation of lust to be full of love or hate. Freedom and intellect as center is at the core of progressive Islamic thought, both of which fall into the 2013 Curriculum. On the other hand, the discourse of qisash (the death penalty under Islamic law) enters into murder material as violence. Although murder permission is only granted to qisash, on the same principle "the value of action depends on the intent" may be interpreted in favor of another. Qisash and the use of violence with the intention to enforce the Sharia are one of the discourses and practices of Islamic scholars in Indonesia.

These two discourses are presented simultaneously in Islamic Education textbook, influencing the young generation of Islam through education. The attraction between these two discourses makes the discourse of tolerance put forth half-heartedly. The inclusive Islamic discourse Nurcholis Madjid built on general Islamic Islam (non-Muslim par excellence) and Muslim par-excellence did not appear in the 2013 Curriculum, even Nurcholis Madjid's name as a reference is not found.

\section{Conclusion}

The discourse of tolerance and ukhuwwah (get along with others, brotherhood) as one of the descendants of the inclusive religion is put forward in the Islamic Education textbook of 2013 Curriculum, but with vague, unfamiliar definitions, and does not use the support of strict verses. The uncertainty of the tolerant attitude is indicated in the blurring of references to the Indonesian social context underlying the need for tolerant and reluctant attitudes to mention parties to be tolerated. The vagueness of tolerance discourse is thought to be due to a struggle between progressive and substantive Islam with a strong Islamism in post-reform Indonesia.
The ambiguity of this discourse of tolerance shows the inclusive religious discourse that substantive Muslims build like Nurcholis Madjid is not supported by the country. The general and specific Islamic argument that should be the basis for tolerance does not appear in the 2013 Curriculum. Tolerance is raised only to the past events occurring in the history of Nabbah, not as a demand for contemporary life.

Nevertheless, at the level of core competence and basic competence, the spirit to begin to make inclusive value is clear. Implementation in Islamic Education textbooks (for students and teachers) shows assertiveness. However, the textbook affects the students, as the Indonesian education system, referring to Parker ${ }^{77}$, is still a 'textbook culture' focusing on book learning. ${ }^{78}$

The Curriculum has shown a positive orientation in building inclusive Muslims, but its implementation in Islamic Education textbooks (for students and teachers) does not show a similar orientation. The textbooks of all levels (elementary, junior high, senior high) should be reviewed, formulated in a new way with an inclusive spirit. Involvement of scholars from official institutions of Islam or Islamic Higher Education can be considered to realize the new textbook.

\section{References}

Abdullah, M. Amin, "Problem Epistemologis Metodologis Pendidikan Islam”, in Abdul Munir Mulkan, Religiusitas Iptek, Pustaka Pelajar, Yogyakarta 1998.

Abidin, Zainal, “Teologi Inklusif Nurcholish Madjid; Harmonisasi antara Keislaman, Keindonesiaan, dan Kemoderenan",Jurnal Humaniora, Vol. 5 No. 2, October 2014.

Akker, J. van den, Curriculum Perspectives: An Introduction. In Curriculum Landscapes and Trends, J. van den Akker (eds.). Springer

77 Lyn Parker, "Religious environmental education? The new school curriculum in Indonesia, Environmental Education Research..., p.76.

78 KrishnaKumar, "Origins of India's 'Textbook Culture.."Comparative EducationReview,1988, 32 (4): p.452464; Leigh, Barbara. "Making the Indonesian State: The Role of School Texts."Review ofIndonesian and Malaysian Affairs, 1988, 25 (1): p. 17-43. 
Science+Business Media Dordrecht, 2004 .

Amir Aziz, Ahmad, Neo Moderenisme Islam di Indonesia, PT.RinekaCipta, Jakarta: 1999.

Culla, Adi Suryadi, Masyarakat Madani: Pemikiran, Teori, dan Relevansinya dengan Cita-cita Reformasi, Rajagrafindo Persada, Jakarta, 1999.

Ellis, Arthur K., Exemplars of Curriculum Theory. New York: Routledge, 2013.

Fairclough, Norman, Analysing Discourse: Textual Analysis for Social Research. Routledge. London, 2003.

Fairclough, Norman, Critical Discourse Analysis: The Critical Study of Language. Electronic book, revised 2nd ed. Old Tappan: Taylor and Francis, 2013.

Fearnley-Sander, Mary, and Ella Yulaelawati, "Citizenship Discourse in the Context of Decentralisation: The Case of Indonesia." In Citizenship Curriculum in Asia and the Pacific, edited by L. David Grossman, W. O. Lee, and J.Kerry Kennedy, Hong Kong: Comparative Education Research Centre, University of Hong Kong., 2008.

Ghozali, Abdul Rohim, Atas Nama Agama, Pustaka Hidayah, Bandung, 1998.

Giroux, Henry A., On Critical Pedagogy. Continuum, New York, 2011.

Hidayat Komaruddin, and Ahmad Gaus (eds.), Passing Over, Melintasi Batas Agama, Gramedia, Jakarta: 1999.

Kemendikbud, Pendidikan Agama Islam dan Budi Pekerti Untuk SMA/MA/SMK/MAK Kelas X, 2014. Kersten, Carool, Berebut Wacana Pergulatan Wacana Umat Islam Indonesia Era Reformasi, Mizan, Bandung, 2015.

Khalikin, Akhsanul and Fathuri (eds.), Toleransi Beragama di Daerah Rawan Konflik, Puslitbang Kehidupan Keagamaan, Puslitbang Kehidupan Keagamaan, Jakarta, 2016.

Kirana, Dita, "Enhancing Religious Education: An Attempt to Counter Violent Extremism in Indonesia", Studia Islamika, Indonesian Journal for Islamic Studies, Vol. 25, No. 1, 2018 .

Kumar, Krishna, "Origins of India's 'Textbook Culture'." Comparative Education Review 32 (4), 1988.

Latif, Yudi, Negara Paripurna: Historitas, Rasionalitas, Aktualitas Pancasila, Gramedia, Jakarta, 2011.
Law Number 20 of 2003 concerning the National Education System.

Leigh, Barbara, "Making the Indonesian State: The Role of School Texts."Review of Indonesian and Malaysian Affairs, 25 (1), 1991.

Mendikbud (Kementrian Pendidikan dan Kebudayaan) [Ministry of Education and Culture], Dokumen kurikulum 2013 [2013 Curriculum Document]. Jakarta, 2012.

Muhaimin, Rekonstruksi Pendidikan Islam Dari Paradigma Pengembangan, Manajemen Kelembagaan, Kurikulum hingga Strategi Pembelajaran, Jakarta: Raja Grafindo Perkasa, 2009.

Nurcholish Madjid, Islam Agama Kemanusiaan, Jakarta: Paramadina, 1990.

Null, W., Curriculum: from theory to practice. Maryland: Rowman\& Littlefield Publishers, Inc, 2011.

Parker,Lyn, "Religious Environmental Education? The new school curriculum in Indonesia", Environmental Education Research, Bandung: Mizan, 2016.

Peraturan Mentri Pendidikan dan Kebudayaan Nomor 69 Tahun 2013 tentang Kerangka Dasar dan Struktur Kurikulum Sekolah Menengah Atas Madrasah Aliyah (Minister of Education and Culture Regulation No. 69 of 2013 concerning the Basic Framework and Curriculum Structure of Senior High Schools/ Madrasah Aliyah).

Peraturan Mentri Pendidikan dan Kebudayaan Nomor 71 Tahun 2013 tentang Buku Teks pelajaran dan Buku Panduan Guru untuk Pendidikan Dasar dan Menengah (Minister of Education and Culture Regulation Number 71 of 2013 concerning lesson Textbooks and Teacher's Handbook for Primary and Secondary Education.).

Pusat Pengkajian Islam dan Masyarakat (PPIM) UIN Syarif Hidayatullah Jakarta "Api dalam Sekam: Keberagamaan gen Z: Survei Nasional tentang Sikap Keberagamaan di Sekolah dan Universitas di Indonesia", November 2017.

Rachman, Budhy Munawar, Ensiklopedi Nurcholis Madjid, Paramadina, Jakarta 2006.

Rachman, Budhy Munawar, Islam Pluralis, Wacana Kesetaraan Kaum Beriman, Paramadina, Jakarta, 2001. 
Raihani, "Education reforms in Indonesia in the Twenty-First Century." International Education Journal,8 (1), 2007.

Rohmatin, Tien, "Nilai-Nilai Pluralisme dalam Buku Pendidikan Agama Islam (PAI) untuk Sekolah Menengah Atas (SMA)", Ilmu Ushuluddin, Vol. 5, No. 1, January 2016.

Ropo, E. and values in education, Published in Rabensteiner, P-M. \& Ropo, E. (Eds.) European Dimension in Education and Teaching, Vol. 2, Schneider Verlag Hohengehren $\mathrm{GmbH}, 2009$. Saunders, Fr. William P., Straight Answers: The Magisterium's 'Imprimatur'”; Arlington Catholic Herald, Inc; Copyright $@ 1999$ Arlington Catholic Herald, Inc. All rights reserved; www. catholicherald.com," translated by YESAYA: www.indocell.net/yesaya with permission from The Arlington Catholic Herald." accessed July 25, 2017
Setara Institute, Setara Institute, Survey Report of "Toleransi Siswa SMA Negeri di Jakarta \& Bandung Raya”, Setara Institute, Jakarta, 2016.

Sukidi, Teologi Inklusif Cak Nur, Kompas, Jakarta, 2001.

Ubaedillah, A. and Abdul Rozak, Pendidikan Kewarganegaraan (Civic Education): Demokrasi, Hak Asasi Manusia, danMasyarakat Madani, $3^{\text {rd }}$ Ed., Prenadamedia Group, Jakarta, 2013. 